\title{
Pengaruh Pengalaman, Independensi, dan Profesionalisme Auditor Internal Dalam Mencegah Kecurangan Pada Bank Perkreditan Rakyat
}

\author{
Dwi Andriyanti ${ }^{1}$ \\ Made Yenni Latrini ${ }^{2}$ \\ ${ }^{1,2}$ Fakultas Ekonomi dan Bisnis Universitas Udayana (Unud), Bali, Indonesia \\ e-mail: andriyanti301@gmail.com
}

\begin{abstract}
ABSTRAK
Penelitian ini bertujuan untuk mengetahui pengaruh pengalaman, independensi, dan profesionalisme auditor dalam mencegah kecurangan pada Bank Perkreditan Rakyat di Kabupaten Badung. Penentuan sampel dalam penelitian ini peneliti menggunakan teknik sampling jenuh. Responden dalam penelitian ini sebanyak 49 orang. Metode pengumpulan data yang digunakan adalah metode sensus dengan instrumen kuesioner. Hasil dari kuesioner penelitian ini diukur dengan menggunakan skala likert. Metode statistik yang digunakan yaitu analisis regresi linier berganda.Hasil penelitian ini menunjukkan bahwa pengalaman, independensi dan profesionalisme auditor internal berpengaruh positif dalam mencegah kecurangan di Bank Perkreditan Rakyat Kabupaten Badung. Hal tersebut berarti semakin baik pengalaman, sikap independensi, dan sikap profesionalisme semakin baik upaya yang dilakukan dalam mencegah kecurangan di Bank Perkreditan Rakyat (BPR) Kabupaten Badung.
\end{abstract}

Kata kunci: kecurangan, auditor internal, pengalaman audit

\begin{abstract}
This study aims to determine the effect of experience, independence, and professionalism of auditors in preventing fraud in the Rural Bank in Badung Regency. Determination of samples in this study the researchers used a saturated sampling technique. Respondents in this study were 49 people. The data collection method used is the census method with the questionnaire instrument. The results of this research questionnaire were measured using a Likert scale. The statistical method used is multiple linear regression analysis. The results of this study indicate that experience, independence and professionalism of internal auditors have a positive effect in preventing fraud in the Badung District Rural Bank. This means that the better the experience, the attitude of independence, and the attitude of professionalism the better the efforts made in preventing fraud in the People's Credit Bank (BPR) of Badung Regency.

Keywords: Prevent fraud, Internal Auditor, Audit experience, Independence
\end{abstract}

\section{PENDAHULUAN}

Bagi para pengguna laporan keuangan, audit merupakan suatu hal yang sangat penting dikarenakan dapat memberikan gambaran terkait pengevaluasian kinerja laporan keuangan dalam waktu periode tertentu (Achmad dan Sumekto, 2016). 
Pemeriksaan ini dilakukan oleh seorang profesi yang biasa disebut auditor. Salah satunya auditor diharapkan mampu memberikan keyakinan kepada para pengguna laporan keuangan perusahaan bahwa laporan keuangan yang diperiksa tidak mengandung salah saji yang material baik yang disebabkan oleh kekeliruan secara sengaja atau kecurangan (fraud).

Kecenderungan kecurangan akuntansi telah menarik banyak perhatian media dan menjadi isu yang menonjol serta penting di mata bisnis dunia. Kecurangan merupakan bentuk penipuan yang sengaja dilakukan sehingga dapat menimbulkan kerugian tanpa disadari oleh pihak yang dirugikan tersebut dan memberikan keuntungan bagi pelaku kecurangan. Kecurangan hingga saat ini merupakan salah satu hal yang fenomenal baik di negara berkembang dan negara maju. Kecurangan merupakan penyimpangan dan perbuatan hukum yang dilakukan secara sengaja, untuk keuntungan pribadi atau kelompok secara fair ; secara langsung dan tidak langsung merugikan pihak lain (Arifin, 2015). Faktor utama yang membedakannya adalah tindakan yang mendasarinya, apakah tindakan tersebut dilakukan secara disengaja atau tidak. Jika tindakan tersebut dilakukan secara sengaja, maka disebut kecurangan dan jika tindakan tersebut dilakukan tidak secara sengaja, maka disebut dengan kekeliruan (errors).

Siaran pers yang dikeluarkan Otoritas Jasa Keuangan SP27/DHMS/OJK/IV/2018 pada tanggal 25 April 2018 tentang kasus kecurangan pada perbankan adalah tindak pidana perbankan yang dilakukan Direktur Utama BPR KS Bali Agung Sedana berinisial NS terkait pemberian kredit kepada 54 debitur dengan nilai Rp24,225 miliar yang tidak sesuai prosedur. Modus operandi 
yang dilakukan NS sebagai Direktur Utama sekaligus sebagai Pemegang Saham PT. BPR KS BAS adalah dengan memerintahkan pegawai BPR untuk memproses pemberian kredit kepada 54 debitur dengan total nilai sebesar Rp. 24,225 miliar pada periode Maret 2014 sampai dengan Desember 2014, yang prosesnya tidak sesuai dengan prosedur sehingga menyebabkan pencatatan palsu dan tidak melaksanakan langkah-langkah yang diperlukan untuk memastikan ketaatan Bank terhadap ketentuan perbankan. (“Siaran Pers SP27/DHMS/OJK/IV/2018,” 2018)

Kasus tersebut merupakan tindakan kecurangan yang terjadi pada perbankan. Adapun faktor penyebab terjadinya kecurangan tidak terlepas dari konsep segitiga kecurangan yaitu tekanan (pressure), kesempatan (opportunity), dan rasionalisasi (rationalization) yang disebut sebagai fraud triangle. Faktor tekanan adalah dorongan yang menyebabkan seseorang melakukan kecurangan yang diakibatkan karena kebutuhan atau masalah finansial. Kedua, faktor kesempatan terjadi karena kurang efektifnya pengendalian internal. Dengan hubungan yang dipercaya dibuat kesempatan untuk melakukan kecurangan menjadi lebih mudah bagi penipu (Dellaportas, 2013). Meskipun memiliki pemisahan tugas di kerangka kerja pengendalian internal untuk mencegah penyalahgunaan aset, karyawan akan dengan senang hati berkolusi satu sama lain untuk menciptakan kesempatan untuk melakukan kecurangan (LaSalle, 2007). Ditambah sebelumnya penelitian Smith, Omar, et al (2005), Omar dan Mohamad Din (2010) juga menunjukkan kesempatam adalah elemen penting ketika menilai risiko kecurangan.Dan ketiga, faktor rasionalisasi dimana sikap pembenaran yang 
Dwi Andriyanti dan Made Yenni Latrini. Pengaruh ...

dilakukan oleh pelaku dengan merasionalkan bahwa tindakan kecurangan adalah sesuatu yang wajar (Wiralestari, 2016)

Pencegahan kecurangan merupakan aktivitas memerangi kecurangan dengan tidak mengeluarkan biaya. Jika menunggu terjadinya kecurangan baru ditangani itu artinya sudah ada kerugian yang terjadi dan telah dinikmati oleh pihak tertentu, bandingkan bila kita berhasil mencegahnya tentu kerugian belum semuanya beralih ke pelaku kecurangan (Windasari dan Juliarsa, 2016). Pencegahan fraud di sektor publik dilakukan dengan mengeluarkan berbagai peraturan perundang-undangan yang menetapkan berbagai sanksi yang diharapkan dapat menangkal atau setidak-tidaknya dapat mengurangi tindakan kecurangan (Imoniana dan Onome, 2013). Pada era globalisasi sekarang ini Bank Perkreditan Rakyat (BPR) dituntut untuk mampu meningkatkan produktivitasnya agar mampu bersaing dengan lembaga keuangan lainnya. Ada tiga konsekuensi logis dari timbulnya persaingan yang semakin tajam, yaitu mundur, bertahan, atau semakin berkembang (Windasari dan Juliarsa, 2016). Semakin berkembang dan semakin kompleknya sistem usaha dan pemerintahan, tidak memungkinkan bagi eksekutif untuk mengawasi semua kegiatan yang menjadi tanggung jawabnya. Tetap saja ada hal-hal yang luput dari perhatian para eksekutif tersebut sehingga kegiatan yang tidak diawasi akan kehilangan efisiensi dan efektivitas. Oleh karena itu, dibutuhkan suatu audit internal untuk memenuhi kebutuhan manajemen perusahaan (Festi T, Andreas, dan Natariasari, 2014).

Belakangan ini perhatian auditor diarahkan terutama untuk mencegah terjadinya kesalahan dan transaksi kecurangan. Oleh karena itu diperlukan 
tindakan strategi represif dan preventif dalam menangani kecurangan. Tujuannya adalah untuk membantu pemimpin perusahaan (manajemen) dalam melaksanakan tanggung jawabnya dengan memberikan analisa, penelitian, saran dan komentar mengenai kegiatan yang diauditnya. Menurut (Amrizal, 2011) internal audit adalah suatu penilaian yang dilakukan oleh pegawai perusahaan yang terlatih mengenai ketelitian, dapat dipercayainya, efisiensi, kegunaan catatan - catatan (akuntansi) perusahaan serta pengendalian internal yang terdapat dalam perusahaan.

Faktor pengalaman memegang peranan yang penting agar auditor dapat mendeteksi adanya tindak kecurangan, karena pengalaman yang lebih akan menghasilkan pengetahuan yang lebih (Putri dan Bandi, 2002). Seseorang yang melakukan pekerjaan sesuai dengan pengetahuan yang dimilikinya akan memberikan hasil yang lebih baik dari pada mereka yang tidak mempunyai pengetahuan cukup atas tugasnya. Windasari dan Juliarsa, (2016) menyatakan bahwa pekerjaan auditor adalah pekerjaan yang melibatkan keahlian (ekspertise). Semakin berpengalaman seorang auditor maka semakin mampu dia menghasilkan kinerja yang lebih baik dalam tugas-tugas yang semakin kompleks, termasuk dalam mencegah kecurangan (fraud) yang kerap terjadi dalam suatu perusahaan (Anggriawan, 2014). Pengalaman auditor dalam penelitian ini adalah ukuran tentang lama waktu dan masa kerjanya yang telah dilalui seorang dalam memahami tugas-tugas pekerjaanya dengan baik (Hamilton \& Wright, 2002).

Independensi bukan hanya dimiliki oleh auditor eksternal namun juga dimiliki oleh auditor internal. Independensi dalam hal ini adalah independensi 
dalam pelaporan. Dimana menurut Razzetti (2003) independensi dalam pelaporan menjadikan auditor internal harus bebas dari perasaan untuk memodifikasi dampak dari fakta - fakta, harus bebas dari hambatan oleh pihak-pihak yang ingin meniadakan auditor dalam memberikan pertimbangan.

Dalam rangka memenuhi persyaratan sebagai seorang professional, auditor harus menjalani pelatihan yang cukup dan kegiatan penunjang keterampilan lainnya. Melalui program pelatihan tersebut para auditor juga mengalami proses sosialisasi agar dapat menyesuaikan diri dengan perubahan situasi yang akan ditemui. Profesionalisme juga menjadi syarat utama bagi seseorang yang ingin menjadi seorang auditor sebab dengan profesionalisme yang tinggi kebebasan auditor akan semakin terjamin. Untuk menjalankan perannya yang menuntut tanggung jawab yang semakin luas, seorang auditor harus memiliki wawasan yang luas tentang kompleksitas organisasi modern. Kurangnya pengetahuan dan pengertian seorang auditor internal mengenai indikasi akan terjadinya tindak kecurangan sering terjadi dan prosedur yang efektif untuk mendeteksi kecurangan sudah sering dibuat sulit oleh auditor - auditor dalam melakukan tugas - tugasnya. Oleh karena itu, seorang auditor internal harus mempunyai keahlian dalam mencegah kecurangan sebagai eksistensi dan pengetahuan mengenai gejala pasti, dan harus mampu mendeteksi segala bentuk kecurangan (fraud) yang terjadi.

Penelitian yang dilakukan oleh Andika (2015), Widiyanturi dan Pamudji (2009) dan Usman dan Rahmawati (2014) menunjukan bahwa pengalaman auditor berpengaruh positif pada pencegahan kecurangan. Namun berbeda dengan hasil penelitian yang diperoleh oleh Sartika N (2012) pengaruh independensi, 
pengalaman, skeptisme professional dan profesionalisme terhadap kemampuan mendeteksi kecurangan menunjukan hasil bahwa pengalaman tidak berpengaruh positif terhadap mendeteksi kecurangan. Dalam penelitian Adnyani, Atmadja, dan Herawati (2014) menggunakan independen sebagai faktor mendeteksi kecurangan dan laporan keuangan auditor dengan hasil penelitian indepedensi berpengaruh positif dalam mendeteksi kecurangan dan kekelirungan laporan keuangan auditor. Begitu juga dengan penelitian Windasari dan Juliarsa (2016) yang menunjukkan bahwa kompetensi, independensi, dan profesionalisme auditor internal berpengaruh positif terhadap kecurangan. Berbeda dengan hasil yang diteliti oleh Karamoy dan Wokas (2015) pengaruh indepedensi dan profesionalisme dalam mencegah dan mendeteksi fraud pada auditor internal, menunjukan bahwa variable independensi tidak berpengaruh positif bagi auditor internal. Penelitian yang dilakukan Sartika N (2012) profesionalisme auditor berpengaruh positif dalam mendeteksi kecurangan. Sedangkan menurut penelitian (Ramadhaniyati dan Hayati (2014), bahwa profesionalisme tidak berpengaruh positif terhadap kinerja auditor internal. Hasil penelitian yang dilakukan oleh Sartika N (2012) dan Ramadhaniyati dan Hayati (2014) terdapat perbedaan karena hasilnya tidak konsisten.

Alasan peneliti ingin meneliti kembali peran audit internal karena, apakah dengan menggunakan variabel yang berbeda dan waktu yang berbeda akan memberikan hasil yang sama dengan penelitian terdahulu. Oleh karena itu, peneliti tertarik untuk meneliti Bank Perkreditan Rakyat di kabupaten Badung. Karena, Bank Perkreditan Rakyat Badung memiliki jumlah BPR terbanyak di 
provinsi Bali dan menurut pengetahuan peneliti masih sedikit penelitian tentang peran auditor internal yang dilakukan di Bank Perkreditan Rakyat Badung. Ditambah lagi dengan adanya Surat Edaran Otoritas Jasa Keuangan Nomor 7/SEOJK.03/2016 tentang Standar Pelaksanaan Fungsi Audit Intern Bank Perkreditan Rakyat yang menyatakan BPR dengan modal inti paling sedikit Rp50.000.000.000,00 (lima puluh milyar rupiah) wajib membentuk Satuan Kerja audit intern (SKAI); atau BPR dengan modal inti kurang dari Rp50.000.000.000,00 (lima puluh milyar rupiah) wajib menunjuk 1 (satu) orang PE Audit Intern.

Januarti (2011) menyatakan bahwa pengalaman adalah keseluruhan perjalanan yang di petik oleh seseorang dari peristiwa-peristiwa yang di alami dalam perjalanan hidupnya. Pengalaman berdasarkan lama bekerja merupakan pengalaman auditor yang dihitung berdasarkan suatu waktu atau tahun. Sehingga auditor yang telah lama bekerja sebagai auditor dapat dikatakan berpengalaman. Karena semakin lama bekerja menjadi auditor, maka akan dapat menambah dan memperluas pengetahuan auditor dibidang akuntansi dan dibidang auditing. Pengalaman merupakan suatu proses pembelajaran dan pertambahan perkembangan potensi bertingkah laku baik dari pendidikan formal maupun non formal atau bisa diartikan sebagai suatu proses yang membawa seseorang kepada suatu pola tingkah laku yang lebih tinggi. Suatu pembelajaran juga mencakup perubahaan yang relatif tepat dari perilaku yang diakibatkan pengalaman, pemahaman dan praktek (Diana, 2010). 
Sukriah, dkk (2009:4) menyimpulkan bahwa semakin banyak pengalaman kerja seorang auditor maka semakin meningkat kualitas hasil pemeriksaan yang dilakukan. Seseorang yang melakukan pekerjaan sesuai dengan pengetahuan yang dimilikinya akan memberikan hasil yang baik daripada mereka yang tidak memiliki pengetahuan yang cukup dalam menjalankan tugasnya. Kenyataan menunjukkan bahwa semakin lama seseorang bekerja maka, semakin banyak pengalaman yang dimiliki pekerja tersebut. Sebaliknya, semakin singkat masa kerja berarti semakin sedikit pengalaman yang diperolehnya. Pengalaman bekerja memiliki keahlian dan keterampilan kerja yang cukup namun sebaliknya, keterbatasan kerja mengakibatkan tingkat keterampilan dan keahlian yang dimiliki semakin rendah. Kebiasaan untuk melakukan tugas dan pekerjaan sejenis merupakan sarana positif untuk meningkatkan keahlian tenaga kerja.

Suardikha (2016) memberikan kesimpulan bahwa seorang yang memiliki pengalaman kerja yang tinggi akan memiliki keunggulan dalam beberapa hal diantaranya; 1). Mendeteksi kesalahan, 2). Memahami kesalahan, dan 3). Mencari penyebab munculnya kesalahan. Keunggulan tersebut bermanfaat bagi pengembangan keahlian. Berbagai macam pengalaman yang dimiliki individu akan mempengaruhi pelaksanakan suatu tugas. Seseorang yang berpengalaman memiliki cara berpikir yang lebih terperinci, lengkap dan sophisticated dibandingkan seseorang yang belum berpengalaman.

Independensi pada auditor dapat berhubungan dengan pengungkapan masalah pengendalian internal suatu perusahaan (Simunic D, 2013). Kebijakan umum kedua dalam SEOJK No. 4 Tahun 2016 menyatakan SKAI (Satuan Kerja 
Audit Internal) atau PE Audit Intern harus bertindak independen dalam melakukan audit dan mengungkapkan pandangan serta pemikiran sesuai dengan profesinya dan standar audit sebagaimana pedoman standar pelaksanaan fungsi audit intern. Auditor internal bekerja di suatu perusahaan untuk melakukan audit bagi kepentingan pihak manajemen. Tugas yang diberikan kepada auditor internal bermacam-macam, tergantung dari perintah dari atasannya. Dalam menjalankan tugasnya seorang auditor internal harus berada diluar fungsi lini suatu organisasi. Seorang auditor internal wajib memberikan informasi yang penting bagi pihak manajemen yang berkaitan dengan proses pengambilan keputusan yang berkaitan dengan operasi suatu perusahaan. Untuk menjadi independen, auditor harus jujur secara intelektual, harus bebas dari kepentingan dalam klien, manajemen, atau pemilik (Abbott, Daugherty, Parker, \& Peters, 2016).

Independen berarti auditor tidak dapat dipengaruhi. Auditor internal tidak dibenarkan memihak kepentingan siapapun. Auditor internal berkewajiban untuk jujur tidak hanya kepada manajemen dan pemilik perusahaan, namun juga pada kreditor dan pihak lain yaitu masyarakat dan pengguna laporan keuangan yang lainnya yang meletakkan kepercayaan pada pekerjaan internal auditor. Jika seorang auditor internal tidak dapat bersikap independen, maka akan sulit dalam upaya mencegah dan mendeteksi terjadinya fraud di perusahaan. Oleh sebab itu, profesi auditor internal akan sangat sensitif terhadap masalah independensi. Dengan demikian sikap independensi sangat dibutuhkan agar laporan keuangan yang disajikan oleh manajer dapat berkualitas dan berkredibilitas dalam mencegah dan mendeteksi terjadinya kecurangan yang ada. 
Profesi merupakan jenis perkerjaan yang memenuhi beberapa kreteria, sedangkan profesionalisme merupakan suatu atribut individual yang penting tanpa melihat apakah suatu pekerjaan merupakan suatu profesi atau tidak. Menurut Kalbers dan Fogarty (1995) dalam Sawyer, (2006) profesionalisme adalah sifatsifat (kemampuan, kemahiran, cara pelaksanaan sesuatu dan lain-lain) sebagaimana yang sewajarnya terdapat dan dilakukan oleh seorang profesional. Penelitian kali ini penulis menganalisis pengaruh pengalaman auditor internal, independensi auditor internal dan profesionalisme auditor internal dalam mencegah kecurangan. Association of Certified Fraud Examiners (ACFE) mendefinisikan kecurangan sebagai tindakan mengambil keuntungan secara sengaja dengan cara menyalahgunakan suatu pekerjaan/jabatan atau mencuri aset/sumberdaya dalam organisasi Singelton (2010) dalam Susilawati dan Atmawinata (2014). Para CEO dari perusahaan audit terbesar mengakui pentingnya auditor deteksi kecurangan (Hammersley, 2011), dan kritik industri mempertanyakan nilai audit yang kurang fokus pada deteksi penipuan (Raslan, 2016).

Meskipun demikian pada dasarnya kecurangan adalah merupakan serangkaian ketidakberesan (irregularities) mengenai: perbuatan-perbuatan melawan hukum (illegal acts), yang dilakukan dengan sengaja untuk tujuan tertentu (misalnya menipu memberikan gambaran yang keliru (mislead) terhadap pihak lain, yang dilakukan oleh orang-orang dari dalam ataupun dari luar organisasi, untuk mendapatkan keuntungan baik pribadi maupun kelompok dan secara langsung atau tidak langsung merugikan orang lain.Kecurangan sering 
terjadi dalam perusahaan, tetapi tak seorang pun dapat melakukan apapun sampai auditor internal maupun eksternal menguji laporan keuangan perusahaan tersebut. Audit internal adalah profesi dan aktivitas yang terlibat dalam memberi saran kepada organisasi mengenai cara mencapai tujuan mereka dengan lebih baik melalui pengelolaan risiko dan meningkatkan kontrol internal (Mui, 2016). Jika kecurangan terjadi, pihak manajemen selalu mempertanyakan bagaimana fungsi dan peran internal auditor yang ada. Dimana dan sedang apa mereka pada saat kasus tersebut terjadi. Kapan pemeriksaan terakhir dilakukan dan mengapa pemeriksaan terakhir tersebut tidak dapat membongkar kecurangan atau setidaknya mengungkapkan kelemahan sistem internal control yang memungkinkan terjadinya kecurangan.

Pengalaman auditor adalah ukuran tentang lama waktu dan masa kerjanya yang telah dilalui seorang dalam memahami tugas-tugas pekerjaanya dengan baik. Hasil penelitian yang dilakukan oleh Ramadhany (2015) membuktikan bahwa pengalaman auditor memiliki pengaruh terhadap kemampuan auditor dalam mendeteksi kecurangan. Hal ini dikarenakan pengalaman kerja dapat memperdalam dan memperluas kemampuan kerja. Semakin sering auditor melakukan pekerjaan yang sama, semakin cepat dan terampil auditor dalam melakukan pekerjaanya. Auditor yang berpengalaman juga akan lebih paham terkait penyebab kekeliruan yang terjadi, apakah karena murni kesalahan baik manusia atau alat ataukah kekeliruan karena kesengajaan yang berarti kecurangan Anggriawan (2014). Penelitian yang dilakukan oleh (Aulia, 2013) mendapatkan hasil bahwa pengalaman auditor berpengaruh positif pada pendeteksian 
kecurangan, hasil penelitian ini juga mendukung penelitian yang dilakukan oleh Matondang (2010), dan Pramitasari, et al. (2017) menyatakan bahwa terdapat pengaruh positif antara pengalaman auditor pada pendeteksian kecurangan. Penelitian sebelumnya oleh Rio Tirta dan Mahfud Solihin, (2013) juga menyebutkan bahwa auditor yang berpengalaman akanmemiliki pengetahuan tentang kekeliruan dan kecurangan yang lebih banyaksehingga akan menghasilkan kinerja yang lebih baik dalam mendeteksi kasus- kasus kecurangan dibandingkan dengan auditor yang tidak berpengalaman.

Berdasarkan uraian diatas, maka hipotesis yang diajukan dalam penelitian ini adalah sebagai berikut:

$\mathrm{H}_{1}$ : Pengalaman auditor internal berpengaruh positif dalam mencegah kecurangan.

Independensi adalah sikap tidak memihak, bebas dari benturan kepentingan dan obyektif dalam melaksanakan suatu pekerjaan. Independensi dalam audit artinya tidak memihak atau menolak segala bentuk campur tangan dari pihak manapun dalam pelaksanaan tugasnya. Independensi berpengaruh penting sebagai dasar utama agar auditor dipercaya oleh masyarakat umum. Jika seorang auditor internal tidak dapat bersikap independen, maka akan sulit dalam upaya mencegah terjadinya fraud.

Wiguna (2014) meneliti mengenai pengaruh independensi auditor terhadap pendeteksian kecurangan berpengaruh positif. Adnyani et al,. (2014) menggunakan independen sebagai faktor mendeteksi kecurangan dan kekeliruan laporan keuangan auditor dengan hasil penelitian indepedensi berpengaruh positif dalam mendeteksi kecurangan dan kekelirungan laporan keuangan auditor. 
Dwi Andriyanti dan Made Yenni Latrini. Pengaruh ...

Ramadhany (2015) menunjukan hasil penelitian yang dilakukannya bahwa independensi berpengaruh terhadap pendeteksian kecurangan. Peneliti dapat menyimpulkan bahwa seorang auditor internal yang profesional harus memiliki independensi untuk memenuhi kewajiban profesionalismenya.

Berdasarkan uraian diatas, maka hipotesis yang diajukan dalam penelitian ini adalah sebagai berikut:

$\mathrm{H}_{2}$ : Independensi auditor internal berpengaruh positif dalam mencegah kecurangan.

Profesionalisme seorang auditor sangatlah dibutuhkan dalam mencegah dan mendeteksi sebuah kecurangan karena semakin tinggi profesionalisme seorang auditor maka semakin terjamin kualitas hasil auditnya. Dengan sikap profesionalisme diharapkan seorang auditor mampu mencegah dan mendeteksi terjadinya fraud. Sikap profesionalisme seorang auditor dapat dilihat dari hasil audit yang ia kerjakan. Auditor yang profesional bekerja tidak pandang bulu, siapapun dia jika menemukan adanya tindak kecurangan, ia akan mengungkapkan kecurangan tersebut.

Dalam penelitian Windasari dan Juliarsa (2016) profesionalisme auditor Internal berpengaruh positif dalam upaya Mencegah terjadinya Fraud. Sedangkan penelitian yang dilakukan Sartika N (2012), profesionalisme auditor berpengaruh positif dalam mendeteksi kecurangan. Karamoy dan Wokas (2015) memperlihatkan bahwa profesionalisme berpengaruh positif dalam mendeteksi fraud pada auditor internal di Provinsi Sulawesi Utara, professional auditor berbanding lurus dengan kemampuan seorang auditor dalam mendeteksi fraud. 
Berdasarkan uraian diatas, maka hipotesis yang diajukan dalam penelitian ini adalah sebagai berikut:

$\mathrm{H}_{3}$ : Profesionalisme auditor internal berpengaruh positif dalam mencegah kecurangan.

\section{METODE PENELITIAN}

Lokasi penelitian ini yaitu Kabupaten Badung. Sasaran yang diamati dalam penelitian ini adalah auditor internal Bank Perkreditan Rakyat. Objek penelitian adalah suatu sifat atau objek yang ditetapkan oleh peneliti untuk mempelajari dan kemudian memperoleh kesimpulamn. Objek dalam penelitian ini adalah mencegah kecurangan yang dipengaruhi oleh pengalaman, independensi, profesionalisme auditor internal.

Populasi dalam penelitian ini yaitu auditor internal Bank Perkreditan Rakyat. Jumlah BPR yang dijadikan sampel dalam penelitian ini adalah sebanyak 51 BPR (OJK, 2018). Dalam penelitian ini peneliti menggunakan teknik sampling jenuh.

Dalam menganalisis hipotesis dalam penelitian ini, metode analisis data yang digunakan adalah Analisis Regresi Berganda. Dalam uji hipotesis penelitian ini terdapat persamaan sebagai berikut:

$\mathrm{Y}=\alpha+\beta_{1} \mathrm{X}_{1}+\beta_{2} \mathrm{X}_{2}+\beta_{3} \mathrm{X}_{3}+\mathrm{e}$

Keterangan dari persamaan diatas adalah sebagai berikut:

$$
\begin{array}{ll}
\mathrm{Y} & =\text { Kecurangan } \\
\mathrm{X}_{1} & =\text { Pengalaman } \\
\mathrm{X}_{2} & =\text { Independensi } \\
\mathrm{X}_{3} & =\text { Profesionalisme } \\
\alpha & =\text { Konstanta }
\end{array}
$$


$\beta_{1} . . \beta_{4}=$ Koefisien regresi yang menunjukan angka peningkatan atau penurunan variabel dependen berdasarkan pada variabel independen

e $\quad=$ Error

\section{HASIL DAN PEMBAHASAN}

Berdasarkan Tabel 1 dapat disimpulkan bahwa jumlah pengamatan $(\mathrm{N})$ penelitian ini berjumlah 49. Variabel pengalaman memiliki nilai minimum sebesar 50 dan memiliki nilai maksimum sebesar 79 rata-rata sebesar 63,90 artinya bahwa respon responden dalam menjawab pernyataan pada kuesioner cenderung merasa setuju pada setiap item pernyataan artinya pengalaman cenderung tinggi. Standar deviasi pada variabel pengalaman adalah sebesar 6.423. Hal ini menunjukkan bahwa standar penyimpangan data terhadap nilai rata-ratanya adalah 6.423.

Tabel 1.

Hasil Statistik Deskriptif

\begin{tabular}{clrrrrr}
\hline No & \multicolumn{1}{c}{ Variabel } & N & Min. & Max. & Mean & $\begin{array}{c}\text { Std. } \\
\text { Deviasi }\end{array}$ \\
\hline 1 & Pengalaman (X1) & 49 & 50 & 79 & 63.90 & 6.423 \\
2 & Independensi (X2) & 49 & 20 & 39 & 29.35 & 4.314 \\
3 & Profesionalisme(X3) & 49 & 20 & 34 & 26.90 & 3.190 \\
4 & Mencegah Kecurangan (Y) & 49 & 43 & 62 & 53.59 & 4.609 \\
\hline Sumber: Data diolah, 2018 & & & & &
\end{tabular}

Variabel kejelasan independensi memiliki nilai minimum sebesar 20 dan nilai maksimum sebesar 39 dengan nilai rata-rata sebesar 29.35 artinya bahwa respon responden dalam menjawab pernyataan pada kuesioner cenderung merasa setuju pada setiap item pernyataan artinya independensi cenderung tinggi. Standar deviasi pada variabel kejelasan sasaran anggaran adalah sebesar 4.314. Hal ini menunjukkan bahwa standar penyimpangan data terhadap nilai rata-ratanya adalah 4.314 .

Variabel profesionalisme memiliki nilai minimum sebesar 20 dan nilai maksimum sebesar 34 rata-rata sebesar 26.90 artinya bahwa respon responden 
dalam menjawab pernyataan pada kuesioner cenderung merasa setuju pada setiap item pernyataan artinya profesionalisme cenderung tinggi. Standar deviasi pada variabel profesionalisme adalah sebesar 3.190. Hal ini menunjukkan bahwa standar penyimpangan data terhadap nilai rata-ratanya adalah 3.190.

Variabel kecurangan memiliki nilai minimum sebesar 43 dan nilai maksimum sebesar 62 dengan nilai rata-rata sebesar 53.59. Nilai rata-rata sebesar 53.59 menunjukkan bahwa respon responden dalam menjawab pernyataan pada kuesioner cenderung merasa setuju pada masing-masing item pernyataan artinya pencegahan kecurangan cenderung tinggi. Standar deviasi pada pencegahan kecurangan yaitu 4.609. Hal ini menunjukkan bahwa standar penyimpangan data terhadap nilai rata-ratanya adalah 4.609.

Jika nilai Asymp. Sig. (2-tailed) lebih besar dari taraf signifikansi yang ditetapkan yaitu 5 persen $(0,05)$, maka data telah berdistribusi normal.

Tabel 2.

Hasil Uji Normalitas

\begin{tabular}{cc}
\hline Kolmogorov-Smirnov & Unstandardized Residual \\
\hline $\mathrm{N}$ & 49 \\
Asymp. Sig. (2-tailed) & 0,848 \\
\hline Sumber: Data diolah, 2018
\end{tabular}

Hasil uji Kolmogorov-Smirnov menunjukkan nilai Asymp. Sig. (2-tailed) sebesar 0.848. Nilai tersebut lebih besar dari signifikan 0,05 sehingga dapat disimpulkan bahwa data mengikuti sebaran normal. Oleh karena itu asumsi normalitas pada regresi telah terpenuhi.

Jika variabel independen memiliki nilai tolerance lebih besar dari $10 \%$ (0.10) dan memiliki nilai Variance Inflation Factor (VIF) kurang dari 10, maka model regresi tersebut bebas dari masalah multikolinieritas. 
Tabel 3.

Hasil Uji Multikolinearitas

\begin{tabular}{clcc}
\hline No & \multicolumn{1}{c}{ Variabel } & Tolerance & VIF \\
\hline 1 & Pengalaman (X1) & 0,170 & 5,886 \\
2 & Independensi (X2) & 0,363 & 2,755 \\
3 & Profesionalisme (X3) & 0,229 & 4,371 \\
\hline Sumber: Data diolah, 2018
\end{tabular}

Sumber: Data diolah, 2018

Tabel diatas menunjukkan bahwa untuk semua variabel independen yang digunakan memiliki nilai VIF yang dihasilkan kurang dari 10 dan nilai tolerance > $10 \%$ (0.10) sehingga dapat disimpulkan bahwa tidak terjadi korelasi ganda (multikolinieritas) antar variabel independen. Oleh karena itu asumsi multikolinieritas telah terpenuhi.

Jika signifikan $\mathrm{t}$ dari hasil meregresi nilai absolute residual terhadap variabel bebas lebih dari 0,05 maka model regresi tidak mengandung hoteroskedastisitas.

Tabel 4.

Hasil Uji Heteroskedastisitas

\begin{tabular}{llcc}
\hline \multicolumn{1}{c}{ Model } & Sig. & Keterangan \\
\hline 1 & (Constant) & & \\
& Pengalaman (X1) & 0,358 & Bebas Heteroskedastisitas \\
& Independensi (X2) & 0,998 & Bebas Heteroskedastisitas \\
& Profesionalisme (X3) & 0,149 & Bebas Heteroskedastisitas \\
\hline
\end{tabular}

Sumber: Data diolah, 2018

Berdasarkan Tabel 4 dapat dilihat bahwa seluruh variabel independen pada penelitian ini yaitu pengalaman, independensi, dan profesionalisme auditor internal menunjukkan nilai sig. masing- masing sebesar 0,$358 ; 0,998 ; 0,149$ > 0,05. Hal ini menunjukkan bahwa model regresi ini bebas dari masalah heteroskedastisitas. 
Hasil analisis regresi linear berganda dapat dilihat pada Tabel 5 berikut ini.

Tabel 5.

Hasil Regresi Linear Berganda

\begin{tabular}{|c|c|c|c|c|c|}
\hline \multirow[t]{2}{*}{ Model } & \multicolumn{2}{|c|}{$\begin{array}{l}\text { Unstandardized } \\
\text { Coefficients }\end{array}$} & \multirow{2}{*}{$\begin{array}{c}\text { Unstandardized } \\
\text { Coefficients } \\
\text { Beta } \\
\end{array}$} & \multirow[t]{2}{*}{$\mathrm{T}$} & \multirow[t]{2}{*}{ Sig. } \\
\hline & $\mathrm{B}$ & Std. Error & & & \\
\hline $1 \quad$ (Constant) & 15.123 & & & & \\
\hline $\mathrm{X} 1$ & 0,294 & 0,111 & 0,409 & 2.657 & 0,011 \\
\hline $\mathrm{X} 2$ & 0,285 & 0,113 & 0,267 & 2.532 & 0,015 \\
\hline $\mathrm{X} 3$ & 0,422 & 0,192 & 0,292 & 2.198 & 0,033 \\
\hline $\mathrm{R}$ & & 0,905 & & & \\
\hline Adjusted $\mathrm{R}^{2}$ & & 0,819 & & & \\
\hline$F_{\text {hitung }}$ & & 67,720 & & & \\
\hline Sig. F & & 0,000 & & & \\
\hline
\end{tabular}

Berdasarkan hasil analisis regresi berganda pada Tabel 5 maka dapat dirumuskan persamaan regresinya sebagai berikut:

$$
\mathrm{Y}=15,123+0.294 \mathrm{X} 1+0.285 \mathrm{X} 2+0.422 \mathrm{X} 3
$$

Nilai koefisien variabel pengalaman bernilai positif sebesar 0.294 maka artinya apabila nilai pengalaman naik satu satuan maka mencegah kecurangan akan naik sebesar 0.294, dengan asumsi variabel lainnya sama dengan nol.

Nilai koefisien variabel independensi bernilai positif sebesar 0.285 maka artinya apabila nilai independensi naik satu satuan maka mencegah kecurangan akan naik sebesar 0.285 , dengan asumsi variabel lainnya sama dengan nol.

Nilai koefisien variabel profesionalisme bernilai positif sebesar 0,422 maka artinya apabila nilai profesionalisme naik satu satuan maka mencegah kecurangan akan naik sebesar 0.422 , dengan asumsi variabel lainnya sama dengan nol.

Koefisien Determinasi (R2) bertujuan mengetahui seberapa besar variabel independen mampu menjelaskan variabel dependen. Analisis regresi yang digunakan adalah analisis regresi berganda maka koefisien determinasi yang digunakan yaitu Adjusted $\mathrm{R}$ square (koefisien determinasi terkoreksi). Nilai 
koefisien yang diperoleh adalah sebesar 0,819. Hal ini mengindikasikan bahwa mencegah kecurangan dijelaskan $81,9 \%$ oleh variabel pengalaman, independensi dan profesionalisme sisanya dijelaskan oleh variabel lain yang tidak dimasukkan ke dalam model atau penelitian.

Uji $\mathrm{F}$ pada dasarnya bertujuan untuk melihat apakah semua variabel independen atau bebas yang dimaksud dalam model mempunyai pengaruh secara serempak terhadap variabel dependen atau terikat. Bedasarkan hasil analisis regresi linier berganda pada Tabel 5 menunjukkan bahwa nilai $\mathrm{F}_{\text {hitung }}$ sebesar 67,720 dengan nilai signifikansi $\mathrm{F}$ atau $p$-value sebesar 0,000 yang lebih kecil dari nilai $\alpha=0,05$. Artinya variabel pengalaman, independensi dan profesionalisme auditor internal berpengaruh signifikan secara simultan dalam mencegah kecurangan.

Berdasarkan hasil uji regresi linear berganda pada Tabel 5 dapat dilihat bahwa variabel pengalaman memiliki nilai t hitung sebesar 2,657 dengan nilai signifikansi sebesar 0,011 . Hal ini menunjukkan bahwa $\mathrm{h}_{\mathrm{o}}$ ditolak dan $\mathrm{H}_{1}$ diterima, yang berarti bahwa pengalaman auditor internal berpengaruh positif dan signifikan dalam mencegah kecurangan.

Berdasarkan hasil uji regresi linear berganda pada Tabel 5 dapat dilihat bahwa variabel independensi memiliki nilai t hitung sebesar 2,532 dengan nilai signifikansi sebesar 0,015 . Hal ini menunjukkan bahwa $\mathrm{h}_{\mathrm{o}}$ ditolak dan $\mathrm{H}_{2}$ diterima, yang berarti bahwa independensi auditor internal berpengaruh positif dan signifikan dalam mencegah kecurangan. 
Berdasarkan hasil uji regresi linear berganda pada Tabel 5 dapat dilihat bahwa variabel profesionalisme memiliki nilai t hitung sebesar 2,198 dengan nilai signifikansi sebesar 0,033. Hal ini menunjukkan bahwa $\mathrm{h}_{\mathrm{o}}$ ditolak dan $\mathrm{H}_{3}$ diterima, yang berarti bahwa profesionalisme auditor internal berpengaruh positif dan signifikan dalam mencegah kecurangan.

Hasil pengujian hipotesis penelitian menunjukkan bahwa ketiga variabel bebas yaitu pengalaman, independensi, dan profesionalisme auditor internal berpengaruh dalam mencegah kecurangan. Hasil pengujian tersebut dapat diberikan pembahasan sebagai berikut

Berdasarkan hasil perhitungan yang ditunjukkan pada Tabel 5 bahwa variabel pengalaman berpengaruh positif dalam mencegah kecurangan pada BPR di Kabupaten Badung. Hal ini ditunjukkan dengan nilai Beta sebesar 0,297 dan nilai signifikansi sebesar 0,011 yang lebih kecil dari tingkat signifikasi yang ditetapkan $(\alpha=0,05)$ sehingga hipotesis pertama $\left(\mathrm{H}_{1}\right)$ diterima. Hasil penelitian menunjukkan semakin tinggi tingkat pengalaman yang dimiliki auditor internal maka kemampuan auditor dalam mencegah kecurangan cenderung semakin tinggi. Sebaliknya semakin rendah tingkat pengalaman yang dimiliki seorang auditor internal maka kemampuan auditor dalam mencegah kecurangan juga cenderung semakin rendah. Hal ini konsisten juga dengan hasil penelitian yang dilakukan oleh Ramadhany (2015), Aulia (2013), Matondang (2010), Pramitasari, et al (2017). Pengalaman yang diperoleh auditor dari lamanya bekerja sebagai auditor dengan banyaknya tugas pemeriksaan yang dilakukan mempengaruhi perilaku auditor dalam pencegahan kecurangan. Dengan kata lain, individu dengan 
Dwi Andriyanti dan Made Yenni Latrini. Pengaruh ...

pengalaman audit yang sama ( sama - sama berpengalaman atau kurang berpengalaman) bisa memiliki pertimbangan etis yang berbeda sehingga akan berperilaku berbeda pula (Matondang, 2010). Dalam penelitian Aprianto (2015) mengatakan bahwa pengalaman merupakan faktor yang mempengaruhi kemampuan prediksi dan deteksi auditor. Selain itu pengalaman mengasah kemampuan seseorang, sehingga auditor yang lebih berpengalaman memiliki keahlian teknis yang lebih baik dalam mencegah kecurangan pada BPR.

Berdasarkan hasil perhitungan yang ditunjukkan pada Tabel 5 bahwa variabel independensi berpengaruh positif dalam mencegah kecurangan pada BPR di Kabupaten Badung. Hal ini ditunjukkan dengan nilai Beta sebesar 0,285 dan nilai signifikansi sebesar 0,015 yang lebih kecil dari tingkat signifikasi yang ditetapkan $(\alpha=0,05)$ sehingga hipotesis pertama $\left(\mathrm{H}_{2}\right)$ diterima. Hasil uji hipotesis menunjukkan bahwa independensi berpengaruh signifikan dalam mencegah kecurangan. Hal ini konsisten juga dengan hasil penelitian yang dilakukan oleh Wiguna (2014), Adnyani et al,. (2014), Ramadhany (2015).

Seorang auditor yang memiliki independensi yang rendah akan mempengaruhi kemampuannya dalam mendeteksi kecurangan, sikap keberpihakan akan mendorong seorang auditor untuk mengabaikan bukti - bukti audit yang mengarah pada pengungkapan kecurangan. Seorang auditor yang tidak menjaga sikap independensinya, akan menghasilkan laporan audit yang tidak sesuai dengan kenyataan atau tidak objektif. Hal tersebut menunjukkan bahwa hasil penelitian sejalan dengan teori yang digunakan bahwa seseorang yang memiliki sikap independensi akan lebih memikirkan tujuan dan tidak dibenarkan 
memihak terhadap kepentingan siapapun. Theory of Planned Behavior merupakan pengembangan dari Theory of Reasoned Action yang dikembangkan oleh (Ajzen, 2011). Theory of attitude and behaviour menjelaskan sikap independensi auditor dalam penampilan. Seorang auditor yang memiliki sikap independen akan berperilaku independen dalam penampilannya, artinya seorang auditor dalam menjalankan tugasnya tidak dibenarkan memihak terhadap kepentingan siapapun auditor mempunyai kewajiban untuk bersikap jujur baik kepada pihak manajemen maupun pihak - pihak lain seperti pemilik, kreditor, investor.

Berdasarkan hasil perhitungan yang ditunjukkan pada Tabel 5 bahwa variabel profesionalisme berpengaruh positif dalam mencegah kecurangan pada BPR di Kabupaten Badung. Hal ini ditunjukkan dengan nilai Beta sebesar 0,422 dan nilai signifikansi sebesar 0,033 yang lebih kecil dari tingkat signifikasi yang ditetapkan $(\alpha=0,05)$ sehingga hipotesis pertama $\left(\mathrm{H}_{2}\right)$ diterima. Hasil uji hipotesis menunjukkan bahwa keahlian profesional berpengaruh signifikan dalam mencegah kecurangan. Hal ini konsisten juga dengan hasil penelitian yang dilakukan oleh Windasari dan Juliarsa (2016), Sartika N (2012), Karamoy dan Wokas (2015).

Theory of planned behavior profesionalisme menjelaskan sikap terhadap perilaku (Windasari \& Juliarsa, 2016). Seseorang yang memiliki profesionalisme ( dalam dedikasi terhadap profesi) yang baik akan membentuk keyakinan pada diri sendiri bahwa profesi yang sedang dikerjakan memberikan hal yang baik bagi individu. Seseorang yang memiliki profesionalisme yang kuat cenderung selalu mematuhi kode etik dan norma - norma yang berlaku dengan tujuan untuk 
Dwi Andriyanti dan Made Yenni Latrini. Pengaruh ...

menghindari pelanggaran yang mungkin terjadi di masa depan yang dapat membahayakan profesinya.

Hasil penelitian ini diharapkan dapat memberikan tambahan informasi mengenai faktor - faktor yang mempengaruhi pencegahan kecurangan yang terdiri dari pengalaman, independensi dan profesionalisme auditor internal. Berdasarkan kesimpulan di atas bahwa variabel pengalaman, independensi, dan profesionalisme auditor internal berpengaruh secara signifikan dalam mencegah kecurangan. Dengan semakin banyaknya pengalaman maka semakin meningkat kualitas hasil pemeriksaan yang dilakukan auditor. Seseorang yang malakukan pekerjaan sesuai dengan pengetahuan yang dimilikinya akan memberikan hasil yang baik daripada mereka yang tidak memiliki pengetahuan yang cukup dalam menjalankan tugasnya. Dan dengan semakin tinggi independensi seorang auditor semakin banyak pula kecurangan yang dapat dicegah dan akan semakin baik kualitas audit serta laporan keuangan yang disajikan lebih berkualitas dan dapat dipercaya. Dalam menjalankan penugasan audit, seorang dituntut untuk selalu mematuhi aturan serta standar profesionalnya agar dapat berperilaku dengan baik dan etis. Terdapat bukti empiris bagi peneliti dalam dalam faktor-faktor yang mempengaruhi pencegahan kecurangan.

Hasil penelitian ini diharapkan mampu memberikan referensi, masukan dan tambahan informasi bagi pihak-pihak yang terkait dalam mencegah kecurangan pada Bank Perkreditan Rakyat di Kabupaten Badung dalam mengambil keputusan dan menentukan kebijakan dalam mencegah kecurangan 
oleh auditor internal sebagai langkah tegas mengurangi resiko timbulnya kerugian finansial maupun non-finansial.

\section{SIMPULAN}

Pengalaman auditor internal memiliki pengaruh positif dan signifikan dalam mencegah kecurangan, dengan tingkat signifikansi sebesar 0,011 ( lebih kecil dari 0,05$)$. Hal ini berarti bahwa auditor yang memiliki pengalaman lebih banyak akan mampu mencegah kecurangan dari pada auditor yang tidak atau kurang mempunyai pengalaman.

Independensi memiliki pengaruh pengaruh positif dan signifikan dalam mencegah kecurangan, dengan signifikansi sebesar 0,015 ( lebih kecil dari 0,05). Hasil ini berarti bahwa semakin tinggi independensi auditor maka kemampuan auditor dalam mencegah kecurangan cenderung semakin tinggi.

Profesionalisme memiliki pengaruh pengaruh positif dan signifikan dalam mencegah kecurangan, dengan signifikansi sebesar 0,033 (lebih kecil dari 0,05). Hasil ini berarti bahwa semakin tinggi sikap profesionalisme seorang auditor maka kemampuan auditor dalam mencegah kecurangan akan cenderung semakin tinggi.

Pengalaman kerja auditor merupakan sebuah pertimbangan dalam melaksanakan audit internal, ada baiknya Bank Perkreditan Rakyat (BPR) memilih auditor yang berpengalaman sehingga dapat mencegah terjadiya kecurangan, karena pada penelitian ini pengalaman berpengaruh positif dan signifikan dalam mencegah kecurangan. 
Untuk auditor yang bekerja pada Bank Perkreditan Rakyat (BPR) diharapkan agar terus meningkatkan independensi auditor yang dimilikinya kearah yang lebih baik, mengingat independensi dan auditor adalah hal yang tidak bisa dipisahkan karena independensi adalah sikap yang wajib dimiliki oleh seorang auditor sehingga memberikan bukti kepada masyarakat bahwa auditor internal pada BPR memiliki independensi yang baik.

Profesionalismr auditor perlu ditingkatkan secara berlanjut dengan tetap berpedoman pada Satuan Kerja Auditor Internal, sehingga diharapkan auditor internal akan bersikap adil, tidak bias, dan yang terutama adalah tidak memihak pada kepentingan pihak - pihak tertentu.

Diharapkan penelitian ini dapat dijadikan pertimbangan oleh penelitian selanjutnya. Untuk peneliti selanjutnya diharapkan memperluas wilayah penelitian dan mengembangkan variabel independen seperti variabel kompetensi, etika profesi, motivasi, dan skeptisme profesional, dan mengukur dengan menggunakan variabel moderating, atau itervening guna mengetahui variabel variabel lain yang dapat memperkuat atau memperlemah variabel dependen.

\section{REFERENSI}

Abbott, L. J., Daugherty, B., Parker, S., \& Peters, G. F. (2016). Internal Audit Quality and Financial Reporting Quality: The Joint Importance of Independence and Competence. Journal of Accounting Research. https://doi.org/10.1111/1475-679X.12099

Achmad, \& Sumekto, A. (2016). Pengaruh Kompetensi, Independensi, dan Tekanan Waktu Terhadap Kemampuan Auditor Mendeteksi Fraud dengan Skeptisme Profesional sebagai Variabel Intervening. Jurnal Sekolah Tinggi Ilmu Ekonomi Perbanas. 
Adnyani, N., Atmadja, A. T., \& Herawati, N. T. (2014). Pengaruh Skeptisme Profesional Auditor, Independensi, dan Pengalaman Auditor Terhadap Tanggungjawab Auditor Dalam Mendeteksi Kecurangan dan Kekeliruan Laporan Keuangan (Studi Kasus pada Kantor Akuntan Publik (KAP) Wilayah Bali). E-Journal AK Universitas Pendidikan Ganesha, 2(1) 1-11.

Ajzen, I. (2011). The theory of planned behaviour: Reactions and reflections. Psychology and Health, 9-2011, 1113-1127. https://doi.org/10.1080/08870446.2011.613995

Amrizal. (2011). Pencegahan dan Pendeteksian Kecurangan Dalam Perusahaan Oleh Internal Auditor. Jurnal Akuntansi Bisnis Dan Publik Program Studi Akuntansi.

Andika, I. G. (2015). Pengaruh Pengalaman , Risiko Audit, Dan Keahlian Audit Terhadap Pendeteksian Kecurangan ( Fraud ) Oleh Auditor ( Survey Pada Kap Di Bandung ). A Journal of Practice \& Theory, 4(2) 67-16.

Anggriawan, E. (2014). Pengaruh Pengalaman Kerja, Skeptisisme Profesional, dan Tekanan Waktu terhadap Kemampuan Mendeteksi Fraud. Jurnal Nominal, 3(2) 30-36. https://doi.org/10.1017/CBO9781107415324.004

Aprianto, N. S. (2015). Pengaruh Independensi, Pengalaman, Due Profesional Care, Akuntabilitas terhadap Kualitas Audit (Studi Empiris Pada Kantor Akuntan Publik di Surakarta dan Yogyakarta). Jurnal Ekonomi Dan Bisnis. https://doi.org/10.1017/CBO9781107415324.004

Arifin. (2005). Peran Akuntan dalam Menegakkan Prinsip Good Corporate Governance pada Perusahaan di Indonesia (Tinjauan Perspektif Teori Keagenan). Jurnal Ekonomi Universitas Diponegoro.

Aulia, M. Y. (2013). Pengaruh Pengalaman, Indepedensi, dan Skeptisisme Profesional Auditor Terhadap Pendeteksian Kecurangan. Jurnal Syarif Hidayatullah, (206082004000), 55-60.

Dellaportas, S. (2013). Conversations with inmate accountants: Motivation, opportunity and the fraud triangle. Accounting Forum. https://doi.org/10.1016/j.accfor.2012.09.003

Diana, F. (2010). Pengaruh Pengalaman Terhadap Peningkatam Keahlian Auditor dalam Bidang Auditing. Auditing: A Journal of Practice \& Theory, 5(1976), 265-288.

Festi T, T., Andreas, \& Natariasari, R. (2014). Pengaruh Peran Audit Internal Terhadap Pencegahan Kecurangan (Studi Empiris Pada Perbankan di Pekanbaru). Jom Fekon. 
Hamilton, R. E., \& Wright, W. F. (2002). Internal Control Judgments and Effects of Experience: Replications and Extensions. Journal of Accounting Research. https://doi.org/10.1016/j.ufug.2015.09.004

Hammersley, J. S. (2011). A Review and Model of Auditor Judgments in FraudRelated Planning Tasks, 30(4), 101-128. https://doi.org/10.2308/ajpt-10145

Imoniana, \& Onome, J. (2013). The forensic accounting and corporate fraud. Journal of Information Systems and Technology Management. https://doi.org/10.4301/S1807-17752013000100007

Januarti, I. (2011). Analisis Pengaruh Pengalaman Auditor, Komitmen Profesional, Orientasi Etis dan Nilai Etika Organisasi Terhadap Persepsi dan Pertimbangan Etis (Auditor Badan Pemeriksa Keuangan Indonesia). Simposium Nasional Akuntansi, 1-37.

Kalbers, L. P., \& Fogarty, T. J. (1995). Professionalism and its consequences: A study of internal auditors. A Jounal of Practive and Theory, 14(1), 64-.

Karamoy, H., \& Wokas, H. R. N. (2015). Pengaruh Independensi dan Profesionalisme dalam Mendeteksi Fraud Pada Auditor Internal Provinsi Sulawesi Utara. Jurnal Riset Akuntansi Dan Auditing, vol.6 no.2.

LaSalle, R. E. (2007). Effects of the fraud triangle on students' risk assessments. Journal of Accounting Education, 25(1-2) 74. https://doi.org/10.1016/j.jaccedu.2007.03.002

Matondang, J. (2010). Pengaruh Pengalaman Audit, Independensi, dan Keahlian Profesional Terhadap Pencegahan dan Pendeteksian Kecurangan Penyajian Laporan Keuangan. Jurnal Akuntansi Bisnis.

Mui, G. Y. (2016). Factors That Impact On Internal Auditors' Fraud Detection Capabilities. Report For The Institute of Internal Auditors Australia, Center for Business Forensics HELP University Malaysia.

Omar, N. B., \& Mohamad Din, H. F. (2010). Fraud diamond risk indicator: An assessment of its importance and usage. In CSSR 2010 - 2010 International Conference on Science and Social Research. https://doi.org/10.1109/CSSR.2010.5773853

Pramitasari, A. P., Sukoharsono, E. G., \& Djamhuri, \& A. (2017). The Influence of Auditor's Personality Types, Experience, Ethics, and Gender on Fraud Detection Capability: Study of Big Four Public Accounting Firm in Indonesia. Imperial Journal of Interdisciplinary Research (IJIR) 
Putri, \& Bandi. (2002). Pengaruh Pengalaman Dan Pelatihan Terhadap Struktur Pengetahuan Auditor Tentang Kekeliruan. Jurnal Akuntansi Fakultas Ekonomi UNS.

Ramadhaniyati, Y., \& Hayati, N. (2014). Pengaruh Profesionalisme, Motivasi, Integritas, Dan Independensi Satuan Pengawasan Internal Dalam Mencegah Kecurangan (Fraud) Di Lingkungan Perguruan Tinggi Negeri. Jurnal Ekonomi Dan Bisnis. https://doi.org/10.1016/j.jmb.2010.09.068

Ramadhany, F. (2015). Pengaruh Pengalaman, Independensi, Skeptisme Profesional, Kompetensi, Dan Komunikasi Interpersonal Auditor KAP Terhadap Pendeteksian Kecurangan (Studi Empiris Pada KAP Di Wilayah Pekanbaru, Medan, dan Batam). Jom FEKON, 2(2) 1-15.

Raslan, I. (2016). Quality Control Elements and Auditor Fraud Risk Assessment : An Experimental Study, 16(2004), 151-176.

Razzetti, E. A. (2003). Internal auditing. Consulting to Management. https://doi.org/10.1016/B978-0-12-417159-6.00003-1

Rio Tirta dan Mahfud Solihin. (2013). The Effect of Experience and TaskSpecific Knowledge on Auditors' Performance in Assessing A Fraud Case. Jurnal Akuntansi Dan Auditing Indonesia, 8 (1)

Sartika N, S. (2012). Pengaruh Independensi, Kompetensi, Skeptisme Profesional Dan Profesionalisme Terhadap Kemampuan Mendeteksi Kecurangan (Fraud) Pada Auditor Di BPK RI Perwakilan Provinsi Sumatera Utara. Jom FEKON, 2(2) $1-13$.

Siaran Pers SP27/DHMS/OJK/IV/2018. (2018). In Otoritas Jasa Keuangan. www.ojk.id.

Simunic D. (2013). Auditing , Consulting , and Auditor Independence. Journal of Accounting Research, 22(2) 679-. https://doi.org/10.2307/2490671

Smith, M., Omar, N. H., Sayd Idris, S. I. Z., \& Baharuddin, I. (2005). Auditors' perception of fraud risk indicators. Malaysian evidence. Managerial Auditing Journal, 20(1) 73-8. https://doi.org/10.1108/02686900510570713

Suardikha, L. W. dan S. (2016). Pengaruh Pelatihan, Pendidikan, Pengalaman Kerja, dan Partipasi Manajemen Pada Efektivitas Penggunaan Sistem Informasi Akuntansi. E-Jurnal Akuntansi Universitas Udayana, 17(2) 2302.

Susilawati, \& Atmawinata, M. R. (2014). Pengaruh Profesionalisme Dan Independensi Auditor Internal Terhadap Kualitas Audit: Studi Pada Inspektorat Propinsi Jawa Barat. Jurnal Etikonomi. 
https://doi.org/10.15408/etk.v13i2.1886

Usman, H., \& Rahmawati. (2014). Pengaruh Beban Kerja Dan Pengalaman Auditor dalam Mendeteksi Kecurangan. Jurnal Akuntansi Dan Investasi.

Widiyanturi, M., \& Pamudji, S. (2009). Pengaruh Kompetensi, Independensi, Dan Profesionalisme Terhadap Kemampuan Auditor Dalam Mendeteksi Kecurangan. Jurnal Akuntansi Bisnis, 5(2), 52-73. https://doi.org/10.1017/CBO9781107415324.004

Wiguna, F. (2014). Pengaruh Skeptisisme Profesional dan Independensi Auditor terhadap Pendeteksian Kecurangan. Jurnal Ekonomi Dan Bisnis, 2(1) 453-4.

Windasari, M. Y., \& Juliarsa, G. (2016). Pengaruh Kompetensi, Independensi dan Profesonalisme Auditor Internal dalam Mencegah Kecurangan. E-Jurnal Akuntansi Universitas Udayana.

Wiralestari. (2016). Fraud: Akuntansi Forensik dan Audit Investigatif. Journal Bakrie, Fakultas Ekonomi Dan Bisnis Jambi, Vol 8 no 1. 